\title{
An Overview of Evapotranspiration Guide for Irrigated Crops in Turkey
}

\author{
Melek Yiğen ${ }^{1}$, Murat Tekiner ${ }^{2 *}$ \\ ${ }^{1}$ Department of Agricultural Structures and Irrigation, Faculty of Agriculture, Çanakkale Onsekiz Mart University, 17020 Çanakkale, Turkey \\ E-mail: melek645@gmail.com,ORCID: https://orcid.org/0000-0002-0675-8440 \\ $2^{2 *}$ Department of Agricultural Structures and Irrigation, Faculty of Agriculture, Çanakkale Onsekiz Mart University, 17020 Çanakkale, Turkey \\ Corresponding author, E-mail: mtekiner@comu.edu.tr, ORCID: https://orcid.org/0000-0002-4624-8496
}

\begin{tabular}{|c|c|}
\hline A R T I C L I N F O & A B S T R A C T \\
\hline $\begin{array}{l}\text { Keywords: } \\
\text { Plant coefficient values }(\mathrm{kc}) \\
\text { Turkey climatic regions } \\
\text { Turkey agriculture basins } \\
\text { Mediterranean Pass } \\
\text { Underpass-Marmara }\end{array}$ & $\begin{array}{l}\text { The "Action Plan for the Water Use in Agriculture Activation Program" in the Tenth Five-Year } \\
\text { Development Plan, prepared by The Ministry of Development for the period 2014-2018, is one of } \\
\text { the most important indicators of the increasing importance of water resources and irrigation. It's } \\
\text { published according to Blaney-Criddle method with the data of the Crop Evapotranspiration } \\
\text { Guideline in 1982, for a guide to be updated by General Directorate of Agricultural Research And } \\
\text { Policies (TAGEM) and General Directorate of State Hydraulic Works (DSI) in 2013, using the } \\
\text { Food and Agriculture Organization (FAO) Penman Monteith method. While DSI undertakes the } \\
\text { calculation of reference plant water consumption (ET } 0 \text { ), effective precipitation and irrigation water } \\
\text { requirement of this update, TAGEM is responsible for the compilation of information obtained } \\
\text { from irrigation researches, calculation of plant coefficient (kc) values, publication of guides in } \\
\text { written and electronic media realized. In this study, five guides (Balikesir, Çanakkale, Edirne, } \\
\text { Kocaeli and Tekirdağ) in three different climatic regions (Akdeniz Ard1, Marmara and İç Geçit- } \\
\text { Marmara) were used in this guide, which the two institutions jointly organize and update with } \\
\text { intensive effort, TUIK 2012-2016 considering the data, the county made on the basis of agriculture } \\
\text { and untreated plants, guide place whether to get cases examined, the importance and aspects to be } \\
\text { developed contacts have tried to reveal. }\end{array}$ \\
\hline
\end{tabular}

Türk Tarım - Gıda Bilim ve Teknoloji Dergisi 7(2): 266-274, 2019

\section{Türkiye'de Sulanan Bitkilerin Bitki Su Tüketimi Rehberi'ne Genel Bir Bakış}

\begin{tabular}{|c|c|}
\hline M A K A L E B İ L G İ S İ & Ö Z \\
\hline $\begin{array}{l}\text { Anahtar Kelimeler: } \\
\text { Bitki katsayısı (kc) } \\
\text { Türkiye iklim bölgeleri } \\
\text { Türkiye tarım havzaları } \\
\text { Akdeniz Ardı } \\
\text { İç Geçit-Marmara }\end{array}$ & $\begin{array}{l}\text { Kalkınma Bakanlığı tarafından 2014-2018 yılları için hazırlanan Onuncu Beş Yıllık Kalkınma } \\
\text { Planında yer alan "Tarımda Su Kullanımının Etkinleştirilmesi Programı Eylem Planı" su } \\
\text { kaynakları ve sulamanın öneminin her geçen gün arttığının en önemli göstergelerinden birisidir. } \\
\text { Araştırma Enstitülerinin verileri ile Blaney-Criddle yöntemine göre } 1982 \text { yılında basılan ve } \\
\text { bugüne kadar kullanılan Bitki Su Tüketim Rehberinin yerine, Dünya Gıda ve Tarım Örgütü (FAO) } \\
\text { Penman Monteith yönteminin kullanılarak güncellenecek bir rehber için } 2013 \text { yılında Tarımsal } \\
\text { Araştırmalar ve Politikalar Genel Müdürlüğü (TAGEM) ve Devlet Su İşleri Genel Müdürlüğü } \\
\text { (DSİ) arasında İkili İşbirliği Protokolü yapılmıştır. DSİ, bu güncellemenin, referans bitki su } \\
\text { tüketimi (ETo), etkili yağış ve sulama suyu ihtiyacı hesaplamalarını üstlenirken, TAGEM de } \\
\text { Araştırma Enstitülerinde yapılmış sulama araştırmalarından elde edilen bilgilerin derlenmesi, bitki } \\
\text { katsayısı (kc) değerlerinin hesaplanması, rehberin yazılı ve elektronik ortamda yayınlanması } \\
\text { işlemlerini gerçekleştirmiştir. Bu çalışmada, iki kurumun ortaklaşa organize olarak yoğun emek, } \\
\text { çaba ve süre harcayarak güncelleştirdiği bu rehberde, üç farklı iklim bölgesindeki (Akdeniz Ardı, } \\
\text { Marmara ve İç Geçit-Marmara) beş ilde (Balıkesir, Çanakkale, Edirne, Kocaeli ve Tekirdağ), } \\
\text { Türkiye İstatistik Kurumu (TÜİK) 2012-2016 verileri dikkate alınarak, ilçe bazında tarımı yapılan } \\
\text { ve yapılmayan bitkilerin rehberde yer alıp almama durumları incelenerek rehberin önemi ve } \\
\text { geliştirilmesi gereken yönleri ortaya konmaya çalışılmıştır. }\end{array}$ \\
\hline
\end{tabular}




\section{Introduction}

Today, the demand for food is increasing with increasing population. Agricultural activities and the management of natural resources have gained importance by increasing food demand. However, the amount of water that is a natural resource that cannot be produced decreases every day for a variety of reasons. As much as $70 \%$ of the available water is consumed by the agricultural sector, which increases the pressure on irrigation management.

A successful irrigation management depends on the good knowledge of the soil-plant-water relations in the first place. The main actor of this relationship is plant water consumption.

As is known, plant water consumption (evapotranspiration) is the sum of the quantities of transpiration from the leaves of the plant with evaporation from the surface of the soil. Plant water consumption values; It is determined for short periods such as daily, weekly and ten days, or for long periods such as monthly and seasonal. While the short-period plant water consumption values are used to determine irrigation interval in irrigation time planning, long period plant water consumption values are also used in determining the average plant water consumption estimates in a specific irrigation project area (Güngör ve ark., 2010).

Plant water consumption is the basic data of an irrigation project and one of the most important elements of irrigation application. The investment costs of large irrigation systems are very high and the realistic parameters in the design of these systems are of great importance in ensuring the expected benefit from the investment to be taken. Among the most important of these parameters, plant water consumption, Crop pattern, properties of water supply, soil and topographic properties, socio-economic structure can be counted (TAGEM, 2016).

No matter how much an irrigation project takes service, the value of plant water consumption is needed in the calculation of the channel capacities and the area to be watered. For this reason, the plant water consumption guide, irrigation planning, sustainable land management, land degradation prevention, field development services and the realization of large irrigation projects is a fundamental resource that is absolutely necessary (TAGEM, 2016).

Blaney-Criddle method has been used so far in our country for the planning stages, project and operation studies to determine the need for plant water needs, due to the need for low meteorological data, account steps and easy data supply. However, instead of the Blaney-Criddle method where limited climate data is used, the PenmanMonteith method, which uses a large number of climatic data, has been widely used in the world. The transition to this method has been inevitable in our country where pressurized irrigation systems are widespread (TAGEM, 2016).

Along with changing climatic and environmental factors, considering the diversity of the products and the technologies the necessity of updating the guidebook has emerged. In this context, bilateral cooperation protocol between TAGEM (General Directorate of Agricultural Research and Policies) and DSI (General Directorate of
State Hydraulic Works) was signed in 2013 for preparing a guidebook to be updated using the FAO Penman-Monteith method instead of the Plant Water Consumption Guidebook which was published in 1982 and used until now. While DSI is carrying out the studies related to reference plant water consumption $\left(\mathrm{ET}_{0}\right)$, effective rainfall and irrigation water requirement calculations, TAGEM has undertaken the compilation the data obtained from irrigation researches at Research Institutes, calculations of plant coefficient values $(\mathrm{kc})$ and publication of the guidebook in hard copy and electronic form.

In this study, in this guide, in which two institutions have been jointly organized by intensive labor, effort and time, in three different climatic regions (Akdeniz Ard1, Marmara and İç Geçit-Marmara) in five provinces (Balıkesir, Çanakkale, Edirne, Kocaeli and Tekirdağ), Turkish Statistical Institute (TUIK) 2012-2016, taking into consideration the data of the region and not being in the directory of plants that are not made in the Guide to the importance of the guideline and the development of the important aspects of the guidance has been put forward.

\section{Regions and Review Criteria Examined in The Guide}

When preparing the guide 24 climate zones (Table 1) in Turkey have been taken into consideration. These 24 regions have been determined based on sea level altitude, monthly and yearly temperatures, annual rainfall, distribution of rainfall in the year and the relationship of precipitation and temperature with the natural vegetation (TAGEM, 2016).

Table 1 Climate regions of Turkey*

\begin{tabular}{l}
\hline \multicolumn{1}{c}{ Regions } \\
\hline 1. Akdeniz \\
2. İlkbaharı Fazla Yağışı Akdeniz \\
3.Akdeniz Ardı \\
4. Akdeniz-Güneydoğu Geçit \\
5. İç Geçit-Marmara \\
6. Marmara \\
7. Ilık Karadeniz \\
8. Serin Karadeniz \\
9. Doğu Karadeniz \\
10. İç Anadolu -İç Geçit -Serin Karadeniz \\
11. İç Anadolu \\
12. Geçit \\
13. Dağ Yamaç \\
14. Dağ Yamacı -Dağ \\
15. Dağ Yamacı -Doğu \\
16. Doğu \\
17. Erzurum -Kars Yaylası \\
18. Iğdır Mikroklima \\
19. Van \\
20. Hakkâri \\
21. Yukarı Fırat -Murat \\
22. Güneydoğu -Geçit \\
23. Güneydoğu-2-3 \\
24. Güneydoğu-1 \\
*M1rak (2014)
\end{tabular}


The provinces of Balıkesir, Çanakkale, Edirne, Kocaeli and Tekirdağ were taken into consideration in the framework of the plants grown in the regions of Marmara, inland Passage-Marmara and Mediterranean region (Table 2). The "List of supported products within the scope of Turkish agricultural basin production and supporting model", published by Republic of Turkey Ministry of Agriculture and Forestry with "herbal production reports" of the last 5 years (2012-2016) from TUIK website of each province, has been investigated. These reports and lists were compared with the mentioned guide and plants without kc coefficient were detected.

This determination was evaluated according to the following phases.

- By taking into consideration the plant groups located on the TUIK web site, on the basis of the province guidelines plants with and without the kc's are put on a table. In these Tables, for the years 2012 - 2016 provincial-based plants cultivated area was given an average area ratio ( 5 years).

- In the provinces surveyed, but not included in the guide, the districts and districts of the provinces in the guide and the five-year average agricultural fields on the basis of the province were given proportional tables.

- In the last five years, the plants with the $\mathrm{kc}$ in the guide on the basis of the province have been given in tables.

- The plants listed in the "List of supported products under the Turkish agricultural basin production and supporting model", prepared by Republic of Turkey Ministry of Agriculture and Forestry, are not included in the guide, but the crops that are not contained in the guideline are shown on the basis of provinces.

\section{Plants and Non-Kc Coefficient in The Guide According to Plant Groups}

By taking into consideration the plant groups located on the TUIK Web site, on the basis of the province, plants with and without kc are given below in the guide (Table 37). In these tables, the average (5 years) field rate (avg.) in the field of agriculture of the plant, between 2012-2016 years, is also based on the province.

Table 3 examined, a total of 27 different grain crops in the province of Balikesir, 15 of them have the $\mathrm{kc}$ coefficient, while the remaining 12 do not. Likewise, 13 of 30 different vegetables have $\mathrm{kc}$ coefficient and the remaining 17 do not. In the group of fruits, only 6 out of 21 plants do not have a kc coefficient in the guide. Given all plant groups, $43(55.13 \%)$ of 78 different plants have kc coefficient in the guide, while the remaining 35 of them $(44.87 \%)$ have no kc coefficient.

A total of 21 different grain crops have been cultivated in Çanakkale province, 9 of them have kc coefficient, but 12 do not. Likewise, 14 of the 29 different vegetables have $\mathrm{kc}$ coefficient and the remaining 15 do not. In the group of fruits, only 9 out of 20 plants do not have a kc coefficient in the guide. Given all plant groups, $34(48.6 \%)$ of 70 different plants have kc coefficient in the guide, while the remaining 36 of them $(51.4 \%)$ have no kc coefficient.

As shown in table 5, 10 of the 22 different grain plants in the Edirne province have a kc coefficient in the guide and the remaining 12 do not. Likewise, 7 of 18 different vegetables have a $\mathrm{kc}$ coefficient in the guide and the remaining 11 do not. In the group of fruits, only 1 out of 13 plants do not have a kc coefficient in the guide. Given all plant groups, 29 of 53 different plants $(54.72 \%)$ have the kc coefficient in the guide, while the remaining 24 $(45.28 \%)$ of the kc coefficient was found.

Table 6 examined, the total of 11 different grains in the province of Kocaeli, 4 of them have the kc coefficient, while the remaining 7 do not have. Likewise, 15 of the 24 different vegetables have kc coefficient and the remaining 9 do not. In the group of fruits, only 9 of the Ise 17 plant is seen in the guide of the kc coefficient of the remaining 8, which is not the kc coefficient. Given all plant groups, half of the total 52 different plants have a kc coefficient in the guide and the other half does not take place in the guide kc coefficient. Given all plant groups, half of the total 52 different plants have a kc coefficient in the guide and the other half does not take place in the guide kc coefficient.

Finally, as shown in table 7,7 of the 15 different grain crops in the province of Tekirdag have the kc coefficient, while the remaining 8 do not. In the same province, 9 of 14 different vegetables have kc coefficient and the remaining 5 do not. In the group of fruits, only 1 out of 10 plants have no kc coefficient in the guide. In all plant groups, 25 of the total 39 different plants $(64.10 \%)$ have kc coefficient in the guide, while the remaining $14(35.90 \%)$ have no kc coefficient.

Table 2 Provinces review in the guide

\begin{tabular}{|c|c|c|c|c|c|}
\hline \multirow{2}{*}{ Regions } & \multicolumn{5}{|c|}{ Provinces } \\
\hline & Balıkesir & Çanakkale & Edirne & Kocaeli & Tekirdağ \\
\hline Akdeniz Ardı & $\begin{array}{c}\text { Ayvalık } \\
\text { Burhaniye } \\
\text { Edremit }\end{array}$ & & & & \\
\hline Marmara & $\begin{array}{c}\text { Merkez } \\
\text { Bandırma } \\
\text { Gönen }\end{array}$ & $\begin{array}{c}\text { Merkez } \\
\text { Bozcaada } \\
\text { Gökçeada }\end{array}$ & İpsala & Merkez & $\begin{array}{l}\text { Merkez } \\
\text { Malkara }\end{array}$ \\
\hline İç Geçit-Marmara & & & $\begin{array}{c}\text { Merkez } \\
\text { Uzunköprü }\end{array}$ & & Çorlu \\
\hline
\end{tabular}


Table 3 The presence of plants in the plant water consumption guide in the province of Balıkesir

\begin{tabular}{|c|c|c|c|c|c|c|c|c|c|}
\hline Crop Group & Crop & AAR & IG & Crop & AAR & IG & Crop & AAR & IG \\
\hline \multirow{9}{*}{ Grains } & Barley & 2.65 & A. & Paddy & 10.68 & A. & Cotton & 1.47 & A. \\
\hline & Sunflower & 7.10 & A. & H. bean & 0.22 & A. & Potato & 0.17 & A. \\
\hline & Safflower & 0.03 & A. & Vetch & 1.08 & UA. & Sorghum & 0.10 & UA. \\
\hline & Broad bean & 0.13 & UA. & Mangel & 0.18 & UA. & Sesame & 0.01 & A. \\
\hline & Pea & 0.08 & UA. & I. Grass & 0.13 & UA. & Sugar beet & 0.13 & A. \\
\hline & Vetch & 0.01 & UA. & Rape & 2.39 & UA. & Triticale & 0.07 & UA. \\
\hline & Wheat & 21.6 & A. & Korunga & 0.01 & UA. & Peanut & 0.03 & UA. \\
\hline & Kidney bean & 0.01 & A. & Corn & 3.97 & A. & Clover & 0.37 & A. \\
\hline & Rye & 0.36 & UA. & Chickpea & 2.60 & A. & Oat & 1.45 & A. \\
\hline \multirow{10}{*}{ Vegetables } & Pumpkin & 0.03 & UA. & Artichoke & 0.02 & UA. & Beetroot & 0.04 & UA. \\
\hline & Broad bean & 0.10 & UA. & Green beans & 0.25 & A. & Cabbage & 0.13 & A. \\
\hline & Okra & 0.66 & A. & Carrot & 0.01 & UA. & Lettuce & 0.08 & UA. \\
\hline & Kidney bean & 0.14 & UA. & Cucumber & 0.06 & A. & Parsley & 0.34 & A. \\
\hline & Pea & 0.38 & UA. & Spinach & 0.11 & UA. & Eggplant & 0.42 & A. \\
\hline & Pepper & 0.24 & A. & Pumpkin & 0.04 & UA. & Leek & 0.16 & A. \\
\hline & Kidney bean & 0.06 & A. & Cauliflower & 0.23 & UA. & Rocket & 0.03 & UA. \\
\hline & Tomato & 1.08 & A. & Watermelon & 0.33 & A. & Onion & 0.21 & A. \\
\hline & Broccoli & 0.10 & UA. & Melon & 0.62 & A. & Cress & 0.01 & UA. \\
\hline & Dill & 0.05 & UA. & Celery & 0.05 & UA. & Radish & 0.03 & UA. \\
\hline \multirow{7}{*}{ Fruits } & Pear & 0.05 & A. & Hazelnut & 0.02 & UA. & Medlar & 0.01 & UA. \\
\hline & Quince & 0.04 & A. & fig & 0.11 & A. & Pomegranate & 0.06 & A. \\
\hline & Almond & 0.06 & A. & Apricot & 0.03 & UA. & Peach & 0.09 & A. \\
\hline & Walnut & 0.23 & A. & Chestnut & 0.02 & UA. & Grape & 0.37 & A. \\
\hline & Strawberry & 0.04 & A. & Cherry & 0.06 & A. & Cherry & 0.06 & UA. \\
\hline & Apple & 0.19 & A. & Kiwi & 0.01 & UA. & Wild apricot & 0.01 & UA. \\
\hline & Plum & 0.14 & A. & Mandarin & 1.23 & UA. & Olive & 51.58 & A. \\
\hline
\end{tabular}

AAR: Av. Area Ratio (\%), IG: In Guide, A. : Available, UA. : Unavailable

Table 4 The presence of plants in the plant water consumption guide of plants that have been cultivated in Çanakkale province

\begin{tabular}{|c|c|c|c|c|c|c|c|c|c|}
\hline Crop Group & Crop & AAR & IG & Crop & AAR & IG & Crop & AAR & IG \\
\hline \multirow{7}{*}{ Grains } & Barley & 7.14 & A. & Haricot bean & 2.17 & A. & Cotton & 0.51 & A. \\
\hline & Sunflower & 7.51 & A. & Verch & 4.12 & UA. & Sorghum & 0.30 & UA. \\
\hline & Broad bean & 0.17 & UA. & İ.grass & 0.58 & UA. & Sesame & 0.33 & A. \\
\hline & Pea & 0.18 & UA. & Rape & 0.01 & UA. & Triticale & 0.08 & UA. \\
\hline & Wheat & 12.43 & A. & Korunga & 0.06 & UA. & Fodder & 0.02 & UA. \\
\hline & Rye & 0.17 & UA. & Corn & 7.58 & A. & Clover & 3.59 & A. \\
\hline & Paddy & 1.72 & A. & Chickpea & 0.83 & UA. & Oat & 1.64 & UA. \\
\hline \multirow{10}{*}{ Vegetables } & Broad bean & 0.03 & UA. & Green beans & 0.05 & A. & Celery & 0.15 & UA. \\
\hline & Pumpkin & 0.01 & UA. & Carrot & 0.00 & A. & Cabbage & 0.08 & A. \\
\hline & Okra & 0.01 & A. & Cucumber & 0.21 & UA. & Lettuce & 0.04 & A. \\
\hline & Kidney bean & 0.01 & UA. & Spinach & 0.17 & UA. & Parsley & 0.02 & A. \\
\hline & Pea & 0.04 & UA. & Pumpkin & 0.02 & UA. & Eggplant & 0.31 & A. \\
\hline & Pepper & 0.58 & A. & Cauliflower & 0.08 & A. & Leek & 0.04 & UA. \\
\hline & Broccoli & 0.04 & A. & Watermelon & 0.32 & A. & Garlic & 0.02 & UA. \\
\hline & Dill & 0.00 & UA. & Melon & 0.58 & A. & Purslane & 0.01 & UA. \\
\hline & Tomato & 2.8 & A. & Beetroot & 0.01 & UA. & Onion & 0.16 & A. \\
\hline & Artichoke & 0.01 & UA. & & & & Radish & 0.01 & UA. \\
\hline \multirow{7}{*}{ Fruits } & Pistachio & 0.01 & UA. & Apple & 0.9 & A. & Medlar & 0.01 & UA. \\
\hline & Pear & 0.10 & UA. & Plum & 0.14 & A. & Pomegranate & 0.09 & A. \\
\hline & Quince & 0.02 & UA. & Vetch & 0.05 & A. & Peach & 2.59 & A. \\
\hline & Almond & 0.48 & A. & Apricot & 0.45 & UA. & Persimmon & 0.05 & UA. \\
\hline & Walnuit & 0.49 & A. & Cherry & 0.4 & A. & Grape & 25.15 & A. \\
\hline & Strawberry & 0.02 & A. & Kiwi & 0.03 & UA. & Cherry & 0.01 & UA. \\
\hline & Mulberry & 0.02 & UA. & & & & Olive & 14.52 & A. \\
\hline
\end{tabular}

AAR: Av. Area Ratio (\%), IG: In Guide, A. : Available, UA. : Unavailable 
Table 5 The presence of plants in the plant water consumption guide in the province of Edirne

\begin{tabular}{|c|c|c|c|c|c|c|c|c|c|}
\hline Crop Group & Crop & AAR & IG & Crop & AAR & $\mathrm{IG}$ & Crop & AAR & $\mathrm{IG}$ \\
\hline \multirow{8}{*}{ Grains } & Barley & 1.22 & A. & Haricot bean & 0.05 & A. & Sesame & 0.05 & UA. \\
\hline & Safflower & 0.01 & UA. & Vetch & 0.43 & UA. & Sugar beet & 0.17 & A. \\
\hline & Sunflower & 27.56 & A. & Mangel & 0.01 & UA. & Triticale & 0.33 & UA. \\
\hline & Pea & 0.20 & UA. & Rape & 0.61 & A. & Fodder & 0.02 & UA. \\
\hline & Wheat & 43.25 & A. & Corn & 2.83 & A. & Peanut & 0.03 & UA. \\
\hline & Rye & 0.13 & UA. & Chickpea & 0.04 & UA. & Clover & 0.34 & A. \\
\hline & Paddy & 22.81 & A. & Potato & 0.03 & A. & Oat & 0.04 & UA. \\
\hline & Sorghum & 0.01 & UA. & & & & & & \\
\hline \multirow{6}{*}{ Vegetables } & Broad bean & 0.04 & UA. & Tomato & 0.09 & A. & Eggplant & 0.06 & A. \\
\hline & Pumpkin & 0.02 & A. & Green beans & 0.06 & A. & Leek & 0.06 & UA. \\
\hline & Okra & 0.01 & UA. & Spinach & 0.03 & UA. & Garlic & 0.03 & UA. \\
\hline & Kidney bean & 0.01 & UA. & Celery & 0.01 & UA. & Purslane & 0.00 & UA. \\
\hline & Pea & 0.01 & UA. & Cabbage & 0.04 & UA. & Onion & 0.10 & A. \\
\hline & Pepper & 0.08 & A. & Parsley & 0.02 & A. & Radish & 0.01 & UA. \\
\hline \multirow{5}{*}{ Fruits } & Pear & 0.02 & A. & Apple & 0.04 & A. & Nectarines & 0.00 & A. \\
\hline & Quince & 0.00 & A. & Plum & 0.01 & A. & Broom & 0.09 & UA. \\
\hline & Almond & 0.05 & A. & Fig & 0.00 & A. & Peach & 0.02 & A. \\
\hline & Walnut & 0.52 & A. & Apricot & 0.00 & A. & Grape & 1.49 & A. \\
\hline & Cherry & 0.03 & A. & & & & & & \\
\hline
\end{tabular}

AAR: Av. Area Ratio (\%), IG: In Guide, A. : Available, UA. : Unavailable

Table 6 The presence of plants in the plant water consumption guide in Kocaeli Province

\begin{tabular}{l|lrrlrrrrr}
\hline Crop Group & \multicolumn{1}{c}{ Crop } & AAR & IG & \multicolumn{1}{c}{ Crop } & AAR & IG & Crop & AAR & IG \\
\hline \multirow{4}{*}{ Grains } & Barley & 15.52 & A. & Rape & 0.02 & UA. & Potato & 0.04 & A. \\
& Sunflower & 1.68 & UA. & Korunga & 0.23 & UA. & Triticale & 0.15 & UA. \\
& Wheat & 15.21 & UA. & Corn & 14.29 & A. & Clover & 4.12 & A. \\
& Vetch & 12.87 & UA. & & & & Oat & 11.16 & UA. \\
\hline \multirow{5}{*}{ Vegetables } & Broad bean & 0.10 & UA. & Cucumber & 0.62 & A. & Parsley & 0.14 & A. \\
& Pumpkin & 0.13 & A. & Spinach & 0.43 & UA. & Eggplant & 0.47 & A. \\
& Kidney bean & 0.26 & UA. & Pumpkin & 0.22 & A. & Leek & 0.04 & A. \\
& Pea & 0.08 & A. & Cauliflower & 0.02 & UA. & Rocket & 0.03 & UA. \\
& Pepper & 1.27 & A. & Watermelon & 0.52 & A. & Garlic & 0.03 & UA. \\
& Tomato & 1.29 & A. & Melon & 0.01 & A. & Purslane & 0.06 & UA. \\
& Artichoke & 0.02 & UA. & Cabbage & 0.31 & A. & Onion & 0.30 & A. \\
& Green beans & 0.59 & A. & Lettuce & 0.67 & A. & Radish & 0.02 & UA. \\
\hline & Pear & 0.56 & A. & Plum & 0.42 & A. & Cherry & 1.74 & A. \\
& Quince & 0.17 & A. & Hazelnut & 6.07 & UA. & Kiwi & 0.08 & UA. \\
& Walnut & 2.42 & A. & Jujube & 0.01 & UA. & Peach & 0.02 & UA. \\
& Strawberry & 0.10 & UA. & Fig & 0.28 & UA. & Persimmon & 0.02 & UA. \\
& Mulberry & 0.03 & UA. & Chestnut & 0.03 & UA. & Grape & 1.03 & A. \\
& Apple & 1.21 & A. & & & & Cherry & 0.27 & A. \\
\hline
\end{tabular}

AAR: Av. Area Ratio (\%), IG: In Guide, A. : Available, UA. : Unavailable

Table 7 The presence of plants in the plant water consumption guide in the province of Tekirdag

\begin{tabular}{|c|c|c|c|c|c|c|c|c|c|}
\hline Crop Group & Crop & AAR & IG & Crop & AAR & $\mathrm{IG}$ & Crop & AAR & $\mathrm{IG}$ \\
\hline \multirow[t]{5}{*}{ Grains } & Barley & 3.71 & A. & Rye & 0.14 & UA. & Korunga & 0.04 & UA. \\
\hline & Safflower & 0.06 & UA. & Paddy & 0.37 & A. & Corn & 0.48 & A. \\
\hline & Sunflower & 16.88 & A. & Vetch & 1.00 & UA. & Triticale & 0.04 & UA. \\
\hline & Pea & 0.53 & UA. & Mangel & 0.02 & UA. & Clover & 0.84 & A. \\
\hline & Wheat & 48.55 & A. & Rape & 7.18 & A. & Oat & 0.18 & UA. \\
\hline \multirow[t]{5}{*}{ Vegetables } & Pumpkin & 0.00 & A. & Cucumber & 0.04 & A. & Cabbage & 0.01 & UA. \\
\hline & Pea & 0.02 & UA. & Spinach & 0.01 & UA. & Lettuce & 0.01 & A. \\
\hline & Pepper & 0.13 & A. & Watermelon & 0.24 & A. & Parsley & 0.00 & UA. \\
\hline & Tomato & 0.10 & A. & Melon & 0.19 & UA. & Garlic & 0.16 & UA. \\
\hline & Green beans & 0.00 & A. & Onion & 0.61 & A. & & & \\
\hline \multirow[t]{4}{*}{ Fruits } & Pear & 0.08 & A. & Walnut & 0.36 & A. & Cherry & 0.06 & A. \\
\hline & Quince & 0.00 & A. & Apple & 0.12 & A. & Peach & 0.01 & A. \\
\hline & Almond & 0.07 & A. & Plum & 0.00 & UA. & Grape & 0.15 & A. \\
\hline & & & & Hazelnut & 0.06 & A. & & & \\
\hline
\end{tabular}




\section{Regions and Agricultural Area Rates Which Are Not Included in The Guide}

The provinces, which are made of agriculture, but not included in the guide, and those districts and districts in the guide, the five-year average agricultural fields on the basis of the provinces were given proportional graphs (Figure 1-5).

As shown in Figure 1, only 6 of the 21 districts in Balikesir are listed in the guide and the remaining 15 are not included. The average agricultural area of the districts 2012-2016, which is not included in the guide, is 64\%, whereas the average agricultural area of the districts with data in the guide is $36 \%$.

In Figure 2, only 3 of the 12 districts in Çanakkale are listed in the guide and the remaining 9 are not included. The average agricultural area of the districts 2012-2016, which is not included in the guide, is $90.4 \%$, whereas the average agricultural area of the districts with the data in the guide is $9.6 \%$.

Only 3 of the 9 districts in Edirne are included in the guide and the remaining 6 are not included (Figure 3). The five-year average agricultural area of the districts, which are not included in the guidebook, is almost equal to each other $(49.7 \%-50.3 \%)$.

In Figure 4, the graphic is examined in Kocaeli Çayırova District, where there is no agricultural activity, only 1 of the remaining 11 districts are shown in the guide. The five-year average agricultural area of 10 counties not included in the guidebook was determined to be $86.4 \%$.

Finally, only 3 of the 12 districts in Tekirdag are included in the guide and the remaining 9 are not included. The average agricultural area of the districts, which is not included in the guide, is $66.4 \%$, while the mean field of agriculture is $33.6 \%$.

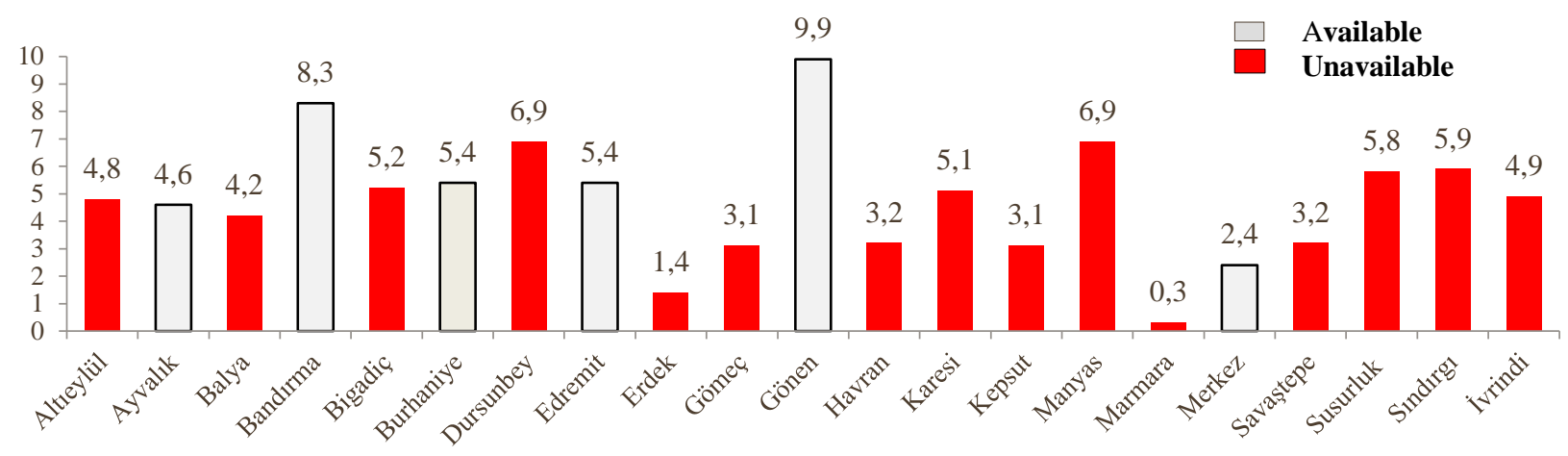

Fig. 1 The average agricultural field rates of Balikesir districts (2012-2016)

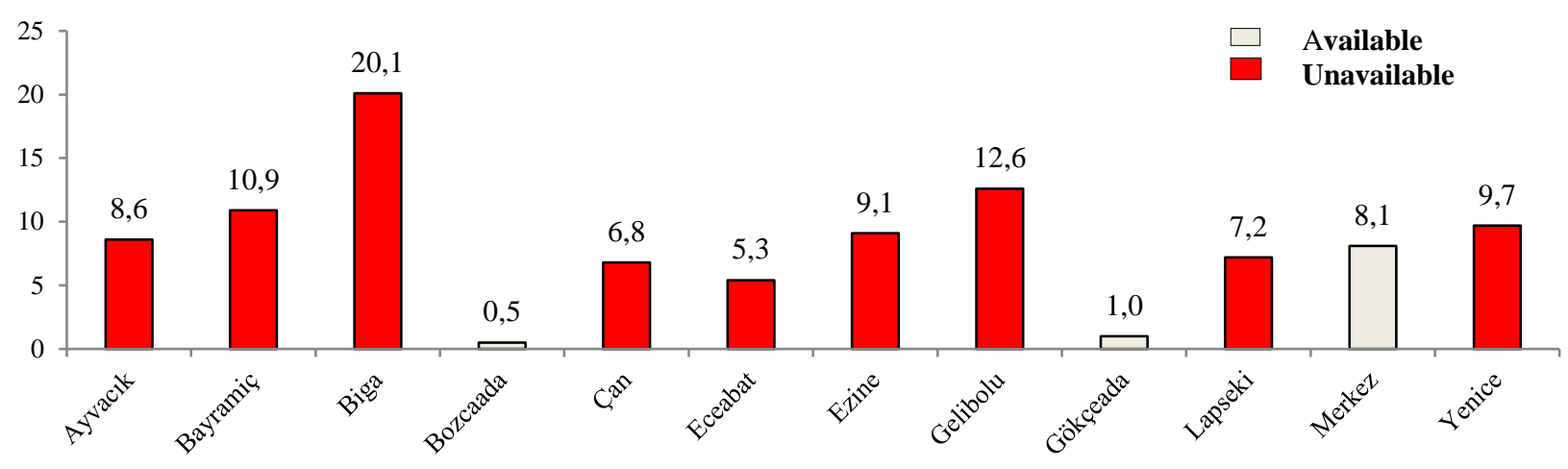

Fig. 2 The average agricultural area rates of Çanakkale districts (2012-2016)

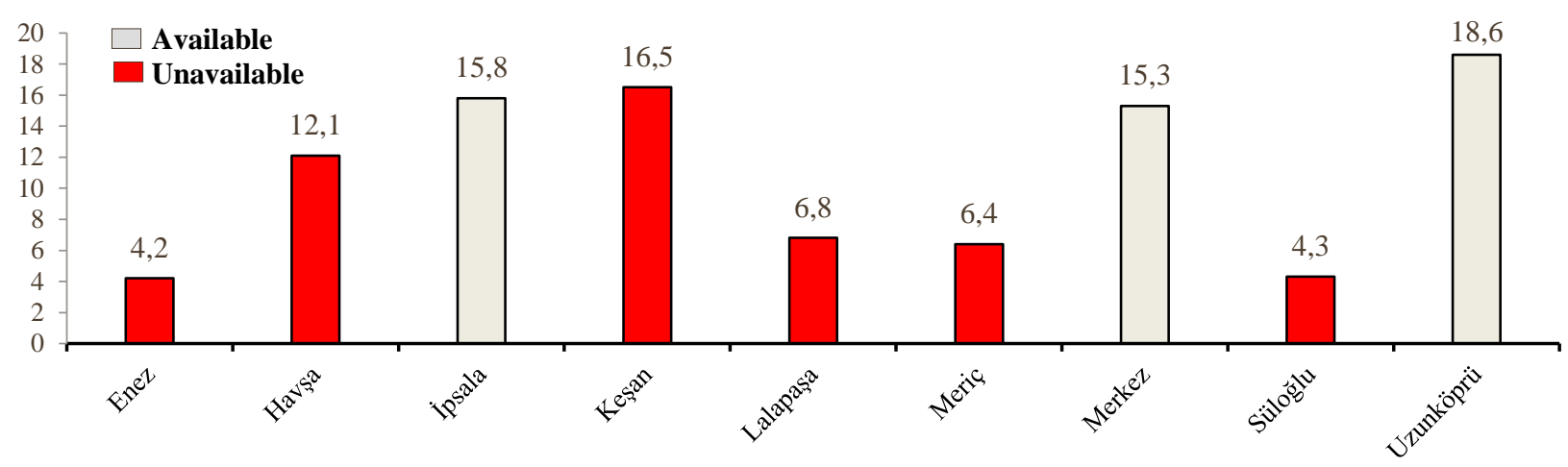

Fig. 3 The average agricultural area of Edirne districts (2012-2016) 


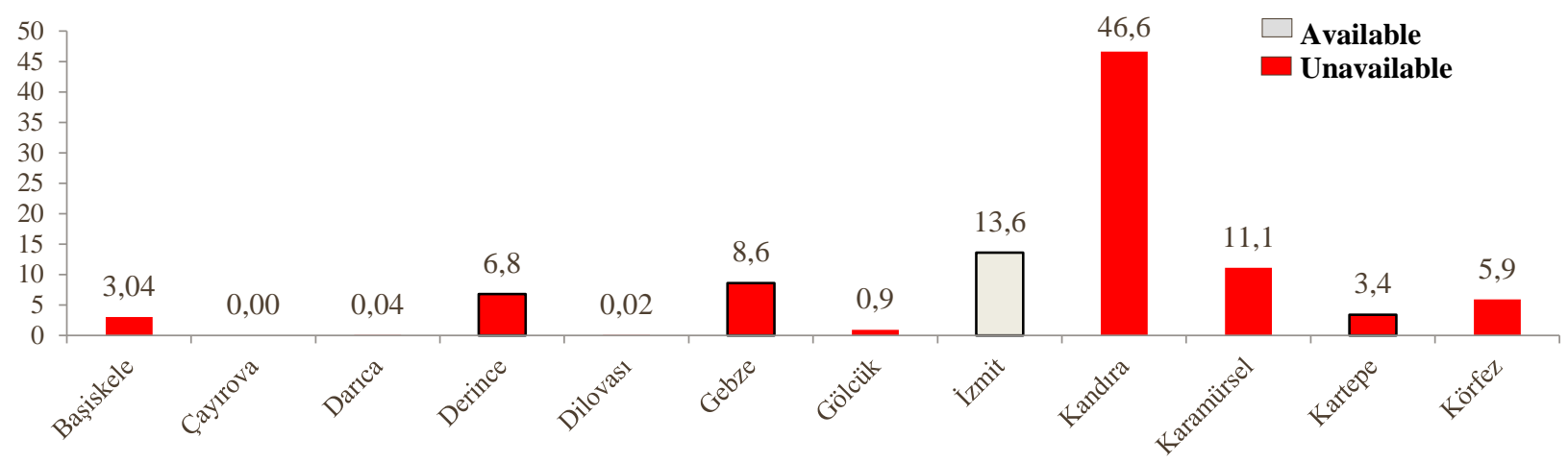

Fig. 4 The average agricultural area rates of Kocaeli districts (2012-2016)

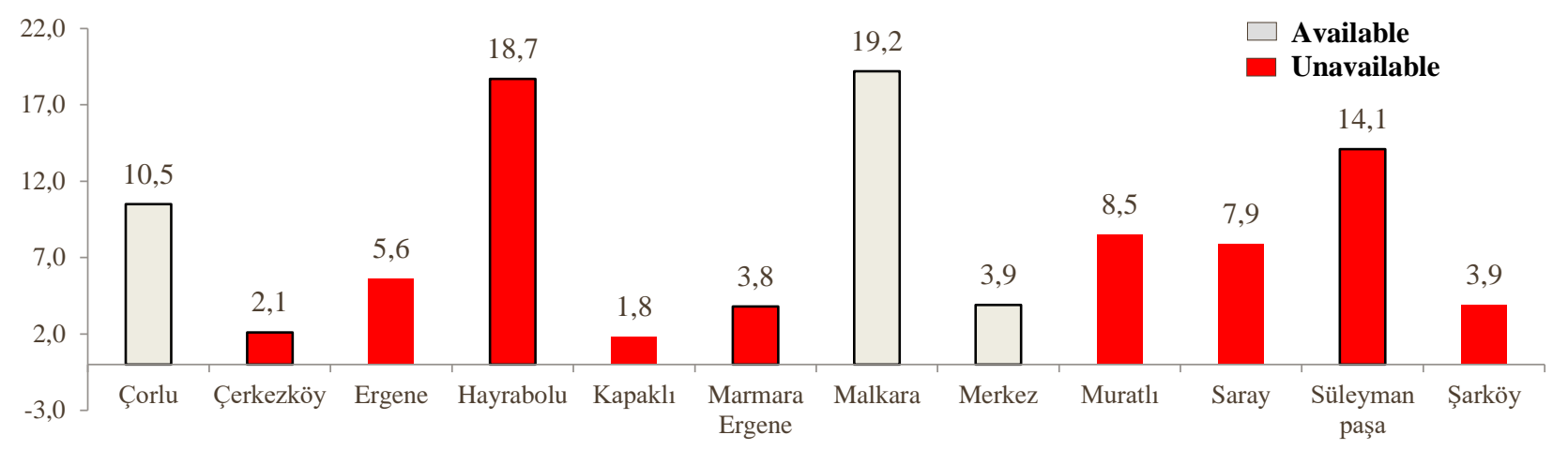

Fig. 5 The average agricultural area of the districts of Tekirdağ (2012-2016)

Table 8 Plants that have a kc coefficient in the guide in the province of Balıkesir, but are not production

\begin{tabular}{|c|c|c|c|c|c|c|}
\hline \multirow{2}{*}{ Crops } & \multicolumn{6}{|c|}{ Districts } \\
\hline & Ayvalık & Bandirma & Burhaniye & Edremit & Gönen & Merkez \\
\hline Anise & + & + & + & + & + & + \\
\hline Quince & & + & & & & \\
\hline Safflower & + & + & + & + & + & + \\
\hline Sunflower & & & + & + & & \\
\hline Okra & & & + & + & & \\
\hline Paddy & + & & + & + & & \\
\hline Strawberry & + & & + & & & \\
\hline Haricot bean & & & & + & & \\
\hline Carrot & & & & + & & \\
\hline Parsley & & & + & & & \\
\hline Cotton & & & & + & + & \\
\hline Potato & & + & + & + & & \\
\hline Sesame & + & & + & + & & \\
\hline Peach & & & + & & & \\
\hline Sugar beet & & & + & + & & \\
\hline Tobacco & & & & & + & \\
\hline Peanut & + & & + & + & & \\
\hline
\end{tabular}

\section{Plants in The Guide but Not Cultivated Plants}

In this section, in the province-based guide, which is the kc coefficient, but the last five years, plants that have not been cultivated in the Tables (Table 8-12) are given in.

As shown in table 8 , the guide $\mathrm{kc}$ in the province of Balikesir, but not being cultivated in Burhaniye and Edremit 12, Ayvalık 6, Bandırma and Gönen 4 and 2 plants in the central district have been identified.

Table 9 examined in the province of Çanakkale in the guide kc coefficient, but not cultivated in Bozcaada 2 and the Central District 1 plant has been identified.
The table prepared for Edirne is 6 in Ipsala, 1 in Uzunköprü and 3 plants in the Central District, although the kc coefficient is not made in the breeding.

In table 11 , the only region in the guide, Kocaeli, which has a coefficient of $\mathrm{kc}$, but the plants that are not being cultivated were found to be peanuts and parsley.

As shown in Table 12, Tekirdağ in Çorlu District 6, Malkara and Central districts of 4 plants in the guide, although the kc coefficient is not made. 
Table 9 Plants that have a kc coefficient in the guide in the province of Canakkale, but are not production

\begin{tabular}{l|ccc}
\hline \multirow{2}{*}{ Bitkiler } & \multicolumn{3}{|c}{ Districts } \\
\cline { 2 - 4 } & Bozcaada & Gökçeada & Merkez \\
\hline Anise & & & + \\
Parsley & + & & \\
Clover & + & & \\
\hline
\end{tabular}

Table 10 Plants that have a kc coefficient in the guide in the province of Edirne, but are not production

\begin{tabular}{l|ccc}
\hline \multirow{2}{*}{ Crops } & \multicolumn{3}{c}{ Districts } \\
\cline { 2 - 4 } Carrot & İpsala & Merkez & Uzunköprü \\
Parsley & & & \\
Fig & + & & \\
Apricot & + & + & \\
Pumpkin & + & & \\
Potato & + & & + \\
Peach & + & + & + \\
Cherry & + & & \\
\hline
\end{tabular}

Table 11 Plants that have a kc coefficient in the guide in the province of Kocaeli, but are not production

\begin{tabular}{l|c}
\hline \multirow{2}{*}{ Crops } & District \\
\cline { 2 - 2 } & Merkez \\
\hline Parsley & + \\
Peanut & + \\
\hline
\end{tabular}

Table 12 Plants that have a kc coefficient in the guide in the province of Tekirdağ, but are not production

\begin{tabular}{l|ccc}
\hline \multirow{2}{*}{ Crops } & \multicolumn{3}{|c}{ Districts } \\
\cline { 2 - 4 } & Çorlu & Malkara & Merkez \\
\hline Paddy & + & & \\
Carrot & + & + & + \\
Haricot bean & + & + & + \\
Parsley & + & & \\
Potato & + & + & + \\
Eggplant & + & + & + \\
\hline
\end{tabular}

\section{Comparison of The List of Supported Products Within the Scope of The Turkish Agricultural Basin Production and Supporting Model}

The 14th edition of the Agricultural Law numbered 5488 by Republic of Turkey Ministry of Agriculture and Forestry. The aim of the "agricultural basin regulation" prepared on the basis of the article is to integrate, support, organize agricultural activities in the agricultural basins determined for the development of agricultural production in appropriate ecology. To organize the procedures and principles related to the specialization and preparation of agricultural inventory. Agricultural basins; Their names and boundaries are determined by the decision of the council of ministers, but the agricultural areas, which have similar ecological conditions within their own boundaries for use in agricultural activities, and that are the continuation of each other, agricultural basin production And the supporting model is the dynamic and the use of information technologies that are used in the planning to be made according to the requirements of the country that evaluates economic, ecological and societal data in basins determined according to the similar natural characteristics of the boundaries. Is defined as a system that can be developed (TCTOB, 2018a)

According to the agricultural basin prepared by Republic of Turkey Ministry of Agriculture and Forestry, the provincial and county list was given in table 13 .

"List of products supported under the Turkish agricultural basin production and support Model" is listed in Table 14 on the basis of provincial plants which are cultivated but not included in the guide.

When table 14 is examined, plants which are supported by the Republic of Turkey Ministry of Agriculture and Forestry but are not included in the guide are in all the provinces predominantly as feed crops, and besides the feed plants in Kocaeli, sunflower and wheat are among the supported products, although it is not included in the guide.

In a nutshell, this compilation works; In this guide, where the two institutions are jointly organized by intensive labor, effort and time, they are currently breeding, although some plants do not have plant water consumption values in some regions and plant water related to these plants.

Consumption studies have been determined not to be carried out in these regions. In this guide some of the provinces and crops grown in these provinces have not been included due to the lack of long-year climate station data. The people and institutions that have updated the guide, so far have been able to work with all plant water consumption based on scientific principles within both universities and research institutes, and can be obtained in a long-year, healthy meteorological There is no doubt that they have created the most comprehensive guide using the data.

Increasing the effectiveness of water usage in agricultural areas has become an important necessity in order to meet the increasing population of the growing food needs in the most economical and most effective way. In order to fulfill this obligation and to obtain quality and adequate products from the unit area, the application of irrigation programs based on scientific principles is inevitable. The Ministry of Development demonstrated that it is aware that "the tenth five-year development plan" has included "the action plan for the activation of water use in agriculture program" as a support for the action plan, irrigation of agricultural areas The development of current guidebook in order to perform irrigation programs based on scientific principles is another necessity. Therefore, it is important to make plant water consumption studies of plants that are being cultivated in districts that are lacking for the development of the guidebook, especially with the relevant public institutions and researchers, mainly TUBITAK and universities. 
Table 13 Provincial and district list of agricultural basins according to provinces examined (TCTOB. 2018b)

\begin{tabular}{|c|c|c|c|}
\hline Basin No & Basin & Province & District \\
\hline 1 & Güney Marmara & $\begin{array}{l}\text { Balıkesir } \\
\text { Çanakkale } \\
\text { Kocaeli }\end{array}$ & $\begin{array}{l}\text { Bandırma, Erdek, Gönen, Manyas, Marmara } \\
\text { Bayramiç, Biga, Çan, Lapseki, Merkez } \\
\text { Başiskele, Çayırova, Darıca, Derince, Dilovası, Gebze, Gölcük, } \\
\text { İzmit, Karamürsel, Kartepe, Körfez }\end{array}$ \\
\hline 2 & Bat1 Karadeniz & Kocaeli & Kandira \\
\hline 6 & Kuzey Marmara & $\begin{array}{l}\text { Çanakkale } \\
\text { Tekirdă̆ } \\
\text { Edirne }\end{array}$ & $\begin{array}{l}\text { Eceabat, Gelibolu, Gökçeada } \\
\text { Çerkezköy, Çorlu, Malkara, M. Ereğlisi, Merkez, Muratlı, Şarköy } \\
\text { Enez, İpsala, Keşan }\end{array}$ \\
\hline 11 & Kiyı Ege & $\begin{array}{l}\text { Balıkesir } \\
\text { Çanakkale }\end{array}$ & $\begin{array}{l}\text { Ayvalık, Burhaniye, Edremit, Gömeç, Havran } \\
\text { Ayvacık, Bozcaada, Ezine }\end{array}$ \\
\hline 14 & Kaz Dağları & $\begin{array}{l}\text { Balıkesir } \\
\text { Çanakkale }\end{array}$ & $\begin{array}{l}\text { Balya, Bigadiç, Dursunbey, İvrindi, Kepsut, Merkez, Savaştepe, } \\
\text { Susurluk } \\
\text { Yenice }\end{array}$ \\
\hline 15 & İç Ege & Balıkesir & Sindirg1 \\
\hline 17 & Meriç & $\begin{array}{l}\text { Edirne } \\
\text { Tekirdağ }\end{array}$ & $\begin{array}{l}\text { Havsa, Lalapaşa, Meriç, Merkez, Süleoğlu, Uzunköprü } \\
\text { Hayrabolu, Saray }\end{array}$ \\
\hline
\end{tabular}

Table 14 In the list of products supported under the Turkish agricultural basins production and support model, plants that are not included in the guide

\begin{tabular}{|c|c|c|c|c|c|}
\hline \multirow{2}{*}{ Crops } & \multicolumn{5}{|c|}{ Provinces } \\
\hline & Balıkesir & Çanakkale & Edirne & Kocaeli & Tekirdağ \\
\hline Sunflower & & & & + & \\
\hline Wheat & & & & + & \\
\hline Rape & + & & & & \\
\hline Triticale & + & + & & + & + \\
\hline Vetch & + & + & + & + & \\
\hline İtalian grass & + & & & & \\
\hline Korunga & + & + & & + & + \\
\hline Sorghum & + & + & + & & \\
\hline Fodder & & & + & & \\
\hline Oat & & & + & + & + \\
\hline
\end{tabular}

\section{References}

Güngör Y, Erözel AZ, Yıldırım O. 2010. Sulama (4. Baskı). Ankara Üniversitesi Ziraat Fakültesi Yayın No:1580. Ders kitabi:532, Ankara.

Mizrak G. 2014. Buğday ve Mamüllerinde Kalite. Türkiye Tohumcular Birliği Dergi Eki. Türkiye Tohumcular Birliği El Kitapları Serisi. No:2, Y11:2., Say1:8.

TAGEM. 2016. Türkiye'de Sulanan Bitkilerin Bitki Su Tüketimi Rehberi. Erişim tarihi: 04.12.2016. https://www.tarim.gov.tr/ TAGEM/Belgeler/T\%C3\%BCrkiyede\%20
TCTOB. 2018a. Tarım Havzaları Yönetmeliği. Erişim Tarihi: 28.06.2018. http://mevzuat. basbakanlik.gov.tr/Metin.Aspx? MevzuatKod=7.5.14262\&MevzuatIliski=0\&sourceXmlSear $\mathrm{ch}=\operatorname{tar} \% \mathrm{C} 4 \% \mathrm{~B} 1 \mathrm{~m}$.

TCTOB. 2018b. Türkiye Tarım Havzaları. Erişim Tarihi: 28.06.2018. https://www.tarim. gov.tr/SGB/TARYAT/ Link/9/Tarim-Havzalari Sulanan\%20Bitkilerin\%20Su\%20 T\%C3\%BCketimi\%20Rehberi\%205-9-2016.pdf.

TUIK. 2018. Bitkisel Üretim İstatistikleri, 18.05.2018. http://www.tuik.gov.tr/PreTablo.do?alt_id=1001. 